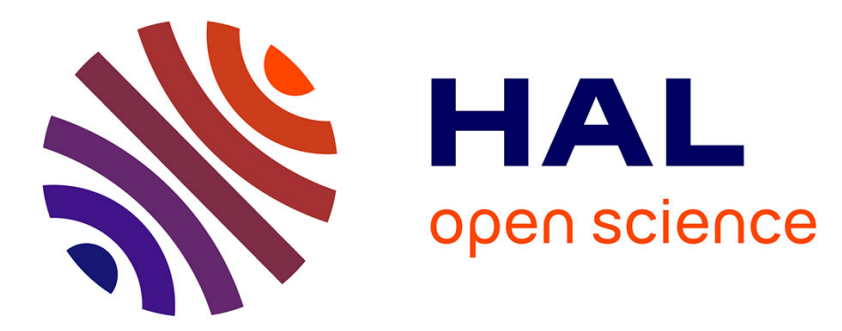

\title{
Orbitally-induced changes of the Atlantic and Indian monsoons over the past 20,000 years: New insights based on the comparison of continental and marine records
} Anne-Marie Lézine, Franck Bassinot, Jean-Yves Peterchmitt

\section{- To cite this version:}

Anne-Marie Lézine, Franck Bassinot, Jean-Yves Peterchmitt. Orbitally-induced changes of the Atlantic and Indian monsoons over the past 20,000 years: New insights based on the comparison of continental and marine records. Bulletin de la Société Géologique de France, 2014, 185 (1), pp.3-12. 10.2113/gssgfbull.185.1.3 . hal-00950703

\section{HAL Id: hal-00950703 https://hal.science/hal-00950703}

Submitted on 8 Mar 2014

HAL is a multi-disciplinary open access archive for the deposit and dissemination of scientific research documents, whether they are published or not. The documents may come from teaching and research institutions in France or abroad, or from public or private research centers.
L'archive ouverte pluridisciplinaire HAL, est destinée au dépôt et à la diffusion de documents scientifiques de niveau recherche, publiés ou non, émanant des établissements d'enseignement et de recherche français ou étrangers, des laboratoires publics ou privés. 


\title{
Orbitally-induced changes of the Atlantic and Indian monsoons over the past 20,000 years: New insights based on the comparison of continental and marine records
}

\author{
ANNE-MARIE LÉZINE ${ }^{1}$, FRANCK BASSINOT ${ }^{2}$ and JEAN-Yves PETERSCHMITT ${ }^{2}$
}

\begin{abstract}
Key-words. - African and Indian monsoon, Last glacial period, Holocene, Continental hydrology, Wind transport, Marine records.
Abstract. - Variations of Atlantic and Indian monsoon systems since the last glacial period are investigated by comparing eolian fluxes from two marine cores (ODP site 658 off western Africa and core 74KL off the Arabian peninsula) with 2147 hydrological records (lacustrine, palustrine, spring and fluvial, arid) gathered over a large continental area extending between 10 and $30^{\circ} \mathrm{N}$ across Africa, Arabia and western India. We show that the hydrological response to the Holocene humid phase in the northern tropics strongly differs from a region to another. The humid period is significantly shorter in the Arabian peninsula and the horn of Africa compared to northern Africa even though its maximum is contemporaneous (11,000-7,000 cal yr BP). Western India displays a specific hydrological signal characterized by the importance of well-developed fluvial systems from the Himalayas and the paucity of lakes compared to the other regions. In western India, the humid peak is shifted toward the mid Holocene (8,000-6,000 cal yr BP). Both marine records show a peak between $\sim 11,000$ and 7,000 cal yr BP for the Holocene humid period, in good accordance with African-Arabian records. However, while continental hydrological data suggest that the onset and termination of this humid period might have been relatively progressive, the marine windborne records indicate abrupt transitions, somewhat out-of-phase with continental evidence (e.g. abrupt decrease of aeolian proxies as early as 15,000 cal yr BP). Discrepancies between marine and continental likely result from the fact that aeolian fluxes at a given marine location do not simply record monsoon-related changes of humidity over the adjacent continental sources but could be affected also by changes of the source area (e.g., emersion of the Arabo-Persian gulf associated to the glacial, low sea-level stand), and changes in wind intensity and/or direction.
\end{abstract}

\section{Changements orbitaux et variations des moussons atlantique et indienne au cours des derniers 20000 ans : nouveaux développements basés sur la comparaison de données continentales et marines}

\begin{abstract}
Mots-clés. - Mousson africaine et indienne, Dernière période glaciaire, Holocène, Hydrologie continentale, Transport éolien, Enregistrements marins.

Résumé. - Les variations des moussons atlantique et indienne depuis la dernière période glaciaire sont étudiées en comparant les flux éoliens enregistrés dans deux carottes marines (Site ODP 658 au large de l'Afrique occidentale et carotte $74 \mathrm{KL}$ au large de la Péninsule arabique) avec 2147 témoins hydrologiques datés (lacs, marécages, sources, fleuves et témoins d'aridité) provenants d'une vaste zone continentale s'étendant entre 10 et $30^{\circ} \mathrm{N}$ à travers l'Afrique, l'Arabie et l'Inde occidentale . Nous montrons que la réponse hydrologique à la phase humide holocène dans les zones nord-tropicales diffère fortement d'une région à l'autre. La période humide est nettement plus courte dans la Péninsule arabique et la Corne de l'Afrique par rapport à l'Afrique du Nord, même si son maximum est contemporain (11,000-7,000 cal BP). L'Ouest de l'Inde affiche un signal hydrologique spécifique caractérisé par l'importance de systèmes fluviaux prenant leur source dans l'Himalaya et la rareté des lacs par rapport aux autres régions. Dans cette région, le pic humide est déplacé vers le milieu de l'holocène (8,000-6,000 cal BP). Les deux enregistrements marins montrent un pic entre 11,000 et 7,000 cal BP pour la période humide holocène, en accord avec les enregistrements africains et arabes continentaux. Cependant, alors que les données hydrologiques continentales suggèrent que le début et la fin de cette période humide ont pu être relativement progressifs, les données de transport éolien indiquent des transitions brusques, un peu hors de phase avec les données continentales (par exemple, diminution brutale de proxies éoliens dès 15,000 ans cal BP). Les écarts entre les données marines et continentales trouvent probablement leur explication dans le fait que les flux éoliens n'ont pas seulement enregistré les changements d'humidité liés à la mousson sur les continents adjacents, mais pourraient également être affectées par des changements de zone source (par exemple, émersion du golfe arabo-persique associé à la baisse du niveau de la mer en période glaciaire), et par les changements dans l'intensité et/ou la direction du vent.
\end{abstract}

1. Laboratoire d'Océanographie et du Climat: expérimentation et approches numériques, UMR 7159 UPMC, CNRS, IRD, MNHN, Université Pierre et Marie Curie, Case 100, 4 place Jussieu, 75252 Paris cedex 5, France

2. Laboratoire des Sciences du Climat et de l'Environnement, UMR 8212 CEA, CNRS, UVSQ Orme des Merisiers, 91191 Gif-sur-Yvette cedex, France Manuscript deposited on March 19, 2013; accepted on August 7, 2013. 


\section{INTRODUCTION}

Northern tropical semi-arid and desert areas from Africa, Arabia and western India have experienced high amplitude climate changes during the last thousand years with dramatic effects on human populations. During the early Holocene Humid period, agriculture and animal husbandry extensively developed [Küper and Kröpelin, 2006]. Then, as climate became drier toward the end of the Holocene [e.g., Gupta et al., 2003; Kröpelin et al., 2008], deep social changes accompanied the exploitation of decreasing resources by human populations [e.g., setting of sedentary populations in the Nile valley at the origin of the Pharaonic civilization after 4,500 cal yr BP [Küper and Kröpelin, 2006]; rise of complex social systems at the beginning of the Early Bronze Age in southern Arabia [Lézine et al., 2010]; collapse of the Harappan civilization 3,900 years ago in the Indus valley [Giosan et al., 2012]. Several studies combining proxy data and climate model simulations have shown that changes in insolation controlled by the slow variation of the Earth orbital parameters (mainly precession), have been the major driver of Holocene changes in atmospheric circulation and in the hydrological budget, which are ultimately linked to the afro-asian monsoon system [e.g. COHMAP, 1988; Prell and Kutzbach, 1987; Joussaume et al., 1999; Liu et al., 2003; Marzin and Braconnot, 2009 a,b; Bassinot et al., 2011; Lézine et al., 2011a]. During the first half of the Holocene, orbital configuration resulted in enhanced seasonality in northern tropical areas compared to the late Holocene. The stronger early Holocene insolation during boreal summer led to the increase in inter-hemispheric and land-ocean temperature contrasts, which triggered summer pressure lows over the Tibetan plateau and in the Sahara. This enhanced the monsoon flow from the moist tropical ocean into land during the early Holocene. However, regional feedback mechanisms such as the impact of water column stratification on monsoon inception and intensity [e.g. Ohgaito and Abe-Ouchi, 2007; Braconnot et al., 2008; Marzin and Braconnot, 2009] or the role of vegetation on open water surfaces evaporation/precipitation mechanisms [e.g., Krinner et al., 2012] have been at the origin of short-scale climate variations superimposed to the above mentioned insolation-driven, largescale monsoon changes.

In this article, in order to better unravel the orbitallydriven changes in African and Indian monsoons since the last glacial period, we compare an extensive dataset of continental sedimentary records with two well-known marine records from the sub-tropical eastern Atlantic and western Arabian sea. This comparison makes it possible to address properly the significance of proxy changes and discuss the timing and amplitude of the late Pleistocene-Holocene climate changes in the north tropical areas along a West-East transect extending from the eastern Atlantic ocean, to the northern Indian ocean between 10 and $30^{\circ} \mathrm{N}$. The time-interval studied extends from the last glacial period to the present day.

\section{MODERN CLIMATIC SETTING AND TRANSPORT OF CONTINENTAL SEDIMENTARY MATERIAL TO THE OCEAN}

The climate of the studied area is characterized by seasonal reversal of the atmospheric circulation (fig. 1, two upper panels) and migration of the intertropical convergence zone (ITCZ) with its associated tropical rain belt. In summer, southwesterly surface winds carry moisture from the Atlantic and Indian oceans to the adjacent continents. Atlantic monsoon fluxes penetrate far northward over northern Africa to the tropic of Cancer and eastward to eastern Sudan whereas the easternmost areas of northern Africa are mainly subjected to the Indian monsoon influence. SW Indian monsoon fluxes follow the southern Arabian coasts then penetrate eastward to southern Iran, Pakistan and western India. In winter, Mediterranean depressions penetrate south through the Red sea and the Arabo-Persian gulf corridors whereas strong, northeasterly winds intensify dry conditions over continents. In these arid and semi-arid areas, availability of sediments for aeolian transport from arid and semi-arid areas, together with the vigorous atmospheric circulation result in the transfer of large quantities of lithogenic material to the adjacent oceans providing a direct link between continental climate and marine sedimentation. Airborne lithogenic material from the Sahara and Sahel are transferred over long distances across the sub-tropical Atlantic. Dust source areas are mostly located in mountains foothills where episodic drainage and the wadis opening to fluvial fans provide a large amount of sediment available for aeolian erosion [Washington et al., 2003; Schepanski et al., 2007]. These main sources are located in the Bodélé depression, as well as the central Saharan massifs (Hoggar and Tibesti) and western Sahara. During summer, large dust outbreaks that can be traced as far as the Caribbean are associated with strong convective disturbances in the monsoonal frontal systems, which uplift dust particles to the mid troposphere. These particles are then transported westward by the African easterly jet [Schültz et al., 1981; Pye, 1987; deMenocal et al., 2000a; Goudie and Middleton, 2000].

Over the Arabian sea, sediment trap data and meteorological observations of mineral aerosol concentration indicate that aeolian transport of lithogenic material is also maximal during the summer season [Middleton, 1986; Ackerman and Cox, 1988; Sirocko et al., 1991], and decreases by at least an order of magnitude during the winter season [e.g. Savoie et al., 1987]. Satellite images and mineralogical analyses of windborne particles show that most of the dust transported to the ocean comes from Arabia, with the northernmost transport track running from Mesopotamia via the Arabo-Persian gulf to the coast of Oman [Ackerman and Cox, 1988; Sirocko et al., 1991, 1993]. Most of the fine particles brought to the Arabian sea are convectively lifted from arid areas to the low and mid troposphere where they are transported by northwesterly winds, which override the low-level southwest monsoon winds. In comparison to this dominant transport by mid-troposphere winds, the proportion of lithogenic dust uplifted in Somalia and transported to the Arabian sea by the low-altitude, southwest monsoon winds seem to be relatively insignificant [Sirocko et al., 1991], although Clemens and Prell [1990] reported grain size variations in upper Pleistocene marine sediments that suggest a link with past changes in SW monsoon intensity. A transport by SW monsoon winds is also evidenced by the occurrence of East African pollens in sediments from the Arabian sea [van Campo et al., 1982; Prell and van Campo, 1986]. 

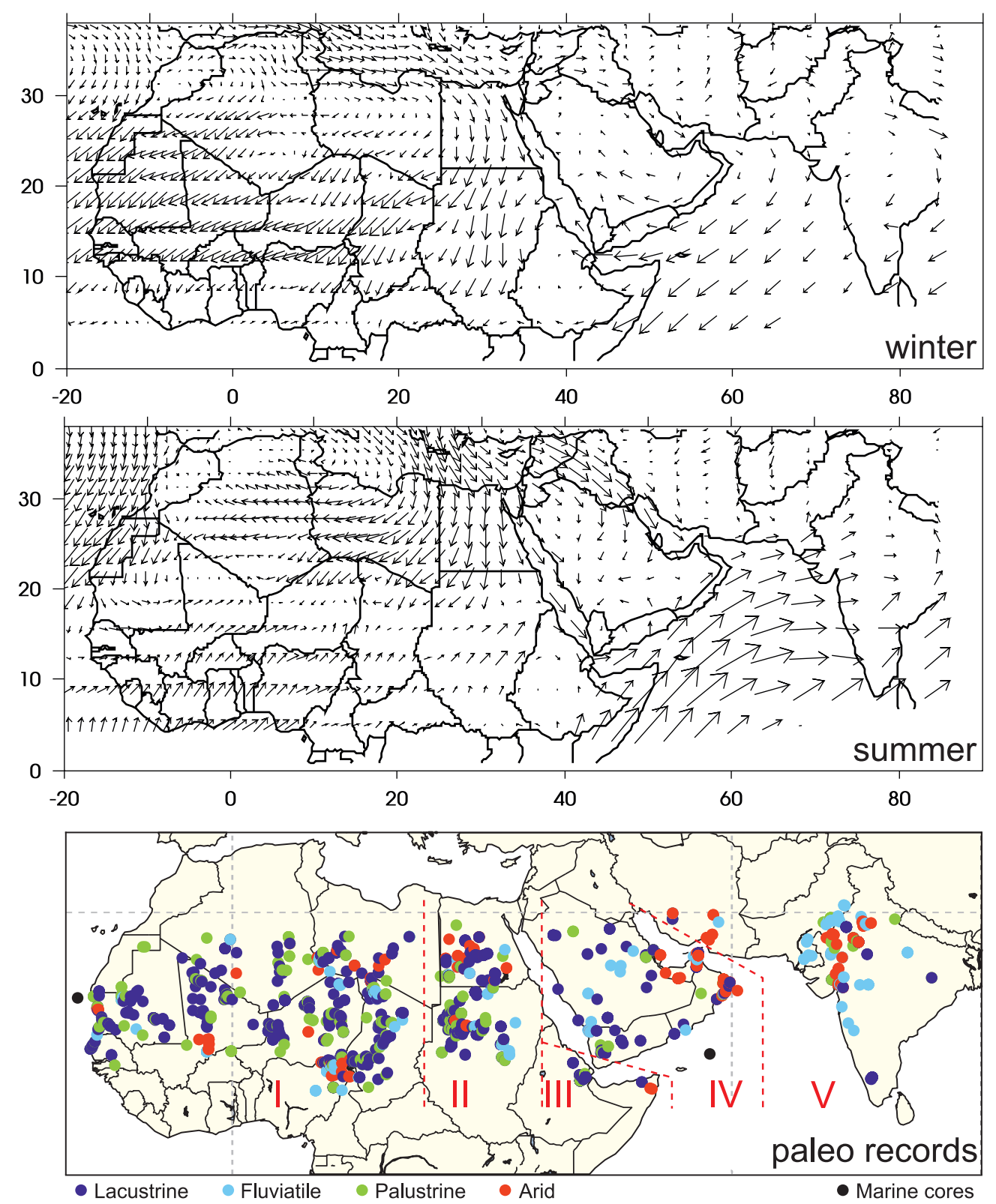

FIG. 1. - Upper panels: surface wind conditions (1000 hP) for winter (DJF) and summer (JJA) months (ECMWF analyses 1990-1997). Lower panel: location of the dated sedimentary records used in this paper. Numbers refer to the four areas detailed on figure 2.

\section{DATA AND METHODS}

\section{Continental data}

Past extension of lakes, wetlands and rivers can be reconstructed from a variety of paleolimnological evidence including abandoned shorelines, sedimentary outcrops, aquatic pollen types from sediment cores, remains of aquatic faunas such as hippos, fishes and shells and fluvial paleo-terraces. Paleohydrological variations can also be inferred from paleosalinity reconstructions based on micro-remain assemblages (diatoms, chronomids, ostracods) and stable oxygen isotope ratios of carbonates (bulk carbonates, ostracods or gastropod calcite...). Our data set is composed of 2147 dated samples extracted from 303 publications (fig. 1, lower panel). This data set covers a wide area, from the present day Sahara and Sahel to eastern
Africa, Arabia and India between 10 and $30^{\circ} \mathrm{N}$. We have grouped these samples into four hydrological categories: (i) "lacustrine", corresponding to high levels/permanent lakes and playas; (ii) "fluvial terraces" and "spring deposits"; (iii) "palustrine", corresponding to intermediate and low lake levels, swamp deposits and paleosoils; and (iv) "arid" including aeolian-formed deposits (sand dunes). Each sample was assigned to its specific category by taking into account the original interpretation of the authors and our own knowledge of tropical paleohydrology [Lézine et al., 2011]. Dating is based (i) on accelerator mass spectrometry (AMS) and conventional radiocarbon dates obtained on lake carbonates, remains of aquatic faunas and organic matter, and (ii) on optically-simulated luminescence and thermoluminence (OSL/TL) dates obtained on quartz grains. Raw ${ }^{14} \mathrm{C}$ dates were converted to calendar ages using CALIB6.0 [Stuiver et al., 2005] taking into account, when possible, 
${ }^{14} \mathrm{C}$ age distortions linked to old carbon from the aquifer [Fontes and Gasse, 1991]. Paleohydrological records from northern Africa have already been discussed in Lézine et al. [2011a]. Additional records located around the Arabian sea (eastern Africa, Arabia, and western India) come from the literature and our own investigations in southern Arabia [Lézine et al., 1998; 2010]. Most of these records are dated levels occurring in discontinuous sedimentary sequences, as is usual under predominantly arid climate conditions.

Our database contains only dated samples. Thus, it may underestimate the full duration of events and may fail to resolve rapid fluctuations of the water level linked to shortterm, climatic changes. These radiocarbon or OSL dates show also various levels of accuracy. Nevertheless, the compilation of a large number of dated samples and their spatial and temporal occurrence should compensate for the discontinuity of individual, sedimentary records and database heterogeneity. One thousand years is the shortest time interval that we can resolve given uncertainties associated with conventional radiocarbon dates. The database only imperfectly reveals the hydrological response to rapid climate fluctuations but gives valuable information on the longterm relations between rainfall patterns, aquifers and fluvial systems over the whole region.

\section{Marine data}

ODP site 658 [deMenocal et al., 2000a,b] and piston core 74KL [Sirocko et al., 1993] provide reference records of regional climate fluctuations during the late Pleistocene and the Holocene in the eastern tropical Atlantic ocean and in the Arabian sea, respectively.

ODP Site 658 provides a detailed ( $100 \mathrm{yr}$ resolution) and well-dated (31 AMS ${ }^{14} \mathrm{C}$ dates to 24,000 cal yr BP) record of aeolian (\% terrigeneous) sedimentation off Cap Blanc, Mauritania $\left(20^{\circ} 45^{\prime} \mathrm{N}, 18^{\circ} 35^{\prime} \mathrm{W}, 2263 \mathrm{~m}\right)$. We used the revised age model published in deMenocal et al. [2000b] in which ${ }^{14} \mathrm{C}$ dates were converted to calendar ages using the CALIB software [Stuiver and Reimer, 1993] and assuming a constant surface reservoir age of $500 \pm 50$ years. The record covers continuously the last $\sim 14,000$ cal yr BP, and from $\sim 17,400$ to 24,500 cal yr BP with a brief hiatus detected between 328 and $324 \mathrm{~cm} \mathrm{(17,400} \mathrm{and} \mathrm{14,300} \mathrm{cal} \mathrm{yr}$ BP). ODP 658 is ideally located to provide a record of dust availability and transport from the subtropical African area since it is positioned below the summer African dust plume, which transports fine terrigeneous minerals from the subSaharan and Sahel regions [Sarnthein, 1978; Tetslaff and Wolter, 1980; Grousset et al., 1998].

Core $74 \mathrm{KL}$ is located in the upwelling area of the western Arabian sea $\left(14^{\circ} 19^{\prime} \mathrm{N}, 5^{\circ} 21^{\prime} \mathrm{E}, 3212 \mathrm{~m}\right)$. The lithogenic material found in core $74 \mathrm{KL}$ is mainly aeolian, originating from the adjacent Arabian area. We focused on the proportion of dolomite, a windborne material derived from Mesozoic strata that are predominant only in the northern Arabia, or from Sebkha sediments around the Persian gulf [Sirocko et al., 1991, 1993; El-Sayed, 1999]. The $\%$ dolomite record of core 74KL [Sirocko et al., 1993] provides a continuous and well-dated (14 AMS ${ }^{14} \mathrm{C}$ dates to $\sim 24,000$ cal yr BP) record of dust availability and transport from the North and East of Arabia. We revised the published age model of core 74KL [Sirocko et al., 1993] by converting the ${ }^{14} \mathrm{C}$ dates to calendar ages using the
CALIB6.0 software [Stuiver and Reimer, 1993; Stuiver et al., 2005] with the recent Marine 09 calibration curve [Reimer et al., 2009] and assuming a global surface reservoir age of $400 \mathrm{yr}$ with a regional correction of $\Delta \mathrm{R}=215 \pm 52$ (estimated based on the 9 most proximal reservoir ages from the database of Southon et al. [2002]). This revision led to calendar ages that are in average $\sim 700$ years younger than the published age model, with a maximum shift of $\sim 1,400$ years at around 14,700 cal yr BP.

Because core $74 \mathrm{KL}$ is located within an upwelling system driven by active Eckman pumping during the SW monsoon, it is likely that reservoir ages may have varied in the past in response to changes in monsoon wind intensity. Saliège et al. [2005] have studied past changes of Holocene reservoir ages in the Arabian sea. Using Saliège et al.'s estimates of past reservoir ages, we constructed an alternate age model. It results in similar calendar ages down to $\sim 5,500$ cal yr BP. During the Holocene climatic optimum, however, alternate ages depart significantly from ages obtained assuming a constant age-reservoir; the alternate ages being about $\sim 600 \mathrm{yr}$ younger at about 8,500 cal yr BP (around the expected maximum of summer wind intensity associated to the peak in boreal summer insolation). Before this period, the age difference drops down to only $\sim 300 \mathrm{yr}$ at $\sim 11,000$ cal yr BP, the lower limit of Saliège et al.'s study. The curve of percent dolomite in core $74 \mathrm{KL}$ is displayed with these two age models on figure 3 .

ODP Site 658 is also located in an upwelling area. Past changes of upwelling intensity have been scrutinized by normalizing carbonate and opal fluxes based on excess ${ }^{230}$ Th [Adkins et al., 2006]. Results show that the early Holocene humid period corresponds to a decrease in coastal upwelling. This decrease in upwelling intensity off western Africa is out of phase, therefore, with the early Holocene increase in western Arabian sea upwelling [e.g., Bassinot et al., 2011]. Although no data is available to estimate and correct past changes in age reservoir at ODP 658, we expect that ${ }^{14} \mathrm{C}$-derived chronologies of sites $74 \mathrm{KL}$ and ODP 658 may be off by several hundred years over specific intervals due to changes in upwelling intensity. This uncertainty should be kept in mind when considering phase relationship between these marine records, as well as between these records and continental datasets.

\section{RESULTS}

\section{Continental data}

In order to subdivide our continental dataset into internally consistent, climate areas, three main regions have been distinguished in Africa based on the respective influence of monsoons originating from the Atlantic and/or the Indian oceans. These three African regions are, from west to east: (i) western Africa from the Atlantic coast to the eastern border of Chad which encompass areas under the predominant influence of the African monsoon, (ii) eastern Africa including Sudan and Egypt, which are also potentially influenced by the Indian monsoon, and (iii) the horn of Africa including northern Ethiopia, Djibouti and Somalia, which is exclusively influenced by the Indian monsoon. Other data from landmasses surrounding the western Indian ocean have 
been grouped into two distinct sub-provinces: the Arabian peninsula (iv) and the western coast of the Indian sub-continent (including Pakistan, Iran and western India (v).

"Arid" (mostly sand dunes) dated samples are irregularly distributed without any direct link with the occurrence of dry areas in the present-day landscape, particularly in Africa. Humid paleohydrological indicators (lacustrine s.l., palustrine and fluviatile) display a rather wide distribution. There are mostly found in Africa with 1445 "humid" records, 848 of which coming from western sites, and 486 from eastern sites. The amount of dated records reflecting humid conditions drops to only 118 in the horn of Africa. A total of 186 dated records reflecting humid conditions has been reached for both Arabia and western India (s.l.) sites. The striking difference in the amount of dated samples indicative of humid conditions that are found in sedimentary records from the five main regions does not simply result from the more or less intensive involvement of the scientific community in specific areas (i.e. the strong German research effort in the eastern Sahara [Lézine et al., 2011a and references therein]). This difference also results from local hydrological and geomorphological conditions, which are not always favorable to the establishment of lakes. In particular, paleolakes are scarce in areas bordering the Arabian sea and the eastern Indian ocean (except in Rajasthan). In the later region, however, fluvial terraces have been extensively studied and provide evidence of variations in past fluvial activity related to monsoon fluctuations [e.g., Sinha et al., 2007]. Our study does not include the Himalayan highlands even though most of the large rivers found in our "western India" area originate from this region. Data explicitely related to tectonic activities and/or sea level fluctuations [Bourget et al., 2010] have been excluded from our inventories.

As can be seen readily in figure 2, hydrological response to changes in African monsoon from 16,000 cal yr BP onward differs considerably from one region to another. In western Africa, the increase in lake expansion is rather progressive, starting from the beginning of the Holocene, at about 15,000 cal yr BP, then accelerating from 12,000 cal yr $\mathrm{BP}$ to reach a maximum at $\sim 9,500 \mathrm{cal} \mathrm{yr} \mathrm{BP}$, in phase with the summer (june-july-august-september; JJAS) insolation maximum at $30^{\circ} \mathrm{N}$ [Berger and Loutre, 1991] (fig. 2). From this optimum period onward, the amount of lake records decreases slowly and regularly to the present. As soon as 8,000 cal yr BP, the development of palustrine areas in association with the progressive decrease of lake records clearly confirms the progressive water table lowering. This trend toward dryness is also reflected by a progressive increase of arid records, which reach their maximum contribution during the last 2,000 cal yr BP. In Sudan and Egypt, the rise of the water table at the beginning of the Holocene appears to be somewhat more abrupt compared to western Africa, with a sharp increase in lake records around 11,000 cal yr BP. Then, the maximum of humidity lasted for about 4 thousand years, from 11,000 to $7,000 \mathrm{cal}$ yr BP. The water table lowering, which started at 8,000 cal yr BP over western Africa, accelerated at 7,000 cal yr BP in eastern Africa and the late Holocene (after 3,000 cal yr BP) was almost completely dry.

In the three remaining areas, which lie today under the influence of the Indian monsoon (horn of Africa, Arabia and western India sectors), two distinct patterns can be distinguished. In the horn of African and Arabia, the evolution of continental hydrology displays a pattern rather similar to that of Sudan and Egypt even though the amount of available dated records is considerably lower. Over western India, continental hydrology is characterized by the large amount of fluvial terraces from 14,000 cal yr BP onwards, which result from abundant rains on the western slope of Himalayan plateaus. In this area, the peak maximum of lacustrine records is delayed by two millennia compared to the other areas, being dated between 8,000 and 6,000 cal yr BP.

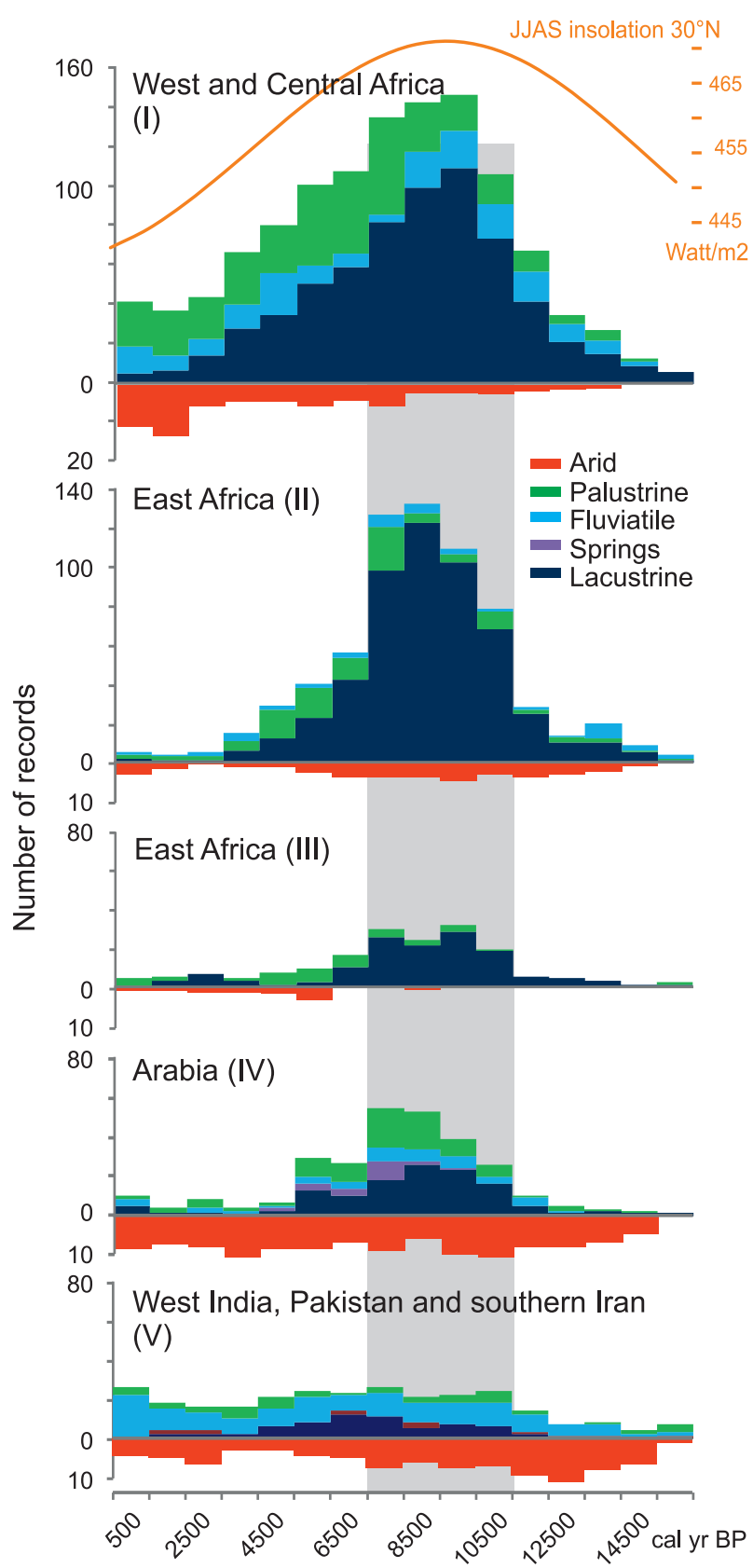

FIG. 2. - Distribution histograms computed over the five studied areas, and showing the respective amount of well-dated lacustrine, palustrine, fluviatile, spring and arid data found in successive 1,000 yr time-slices, from $16,000 \mathrm{cal}$ yr BP to the present. The geographic distribution of the sedimentary sites from which these published data were collected is shown on figure 1. Insolation curve from Berger and Loutre [1991]. 


\section{Marine data}

The eastern Atlantic and Arabian sea aeolian records display striking similarities from the glacial period to the end of the Holocene humid period, around 7,000 cal yr BP (fig. 3). In both records, high values of terrigenous material are measured over the glacial interval. This period of high dust supply ends up rather abruptly in core $74 \mathrm{KL}$, as evidenced by the \%dolomite drop from $14 \%$ to $\sim 0 \%$, which takes place in two successive steps (each lasting less than $\sim 300 \mathrm{yr}$ ) centered at $16,800 \mathrm{cal} \mathrm{yr} \mathrm{BP}$ and $15,100 \mathrm{cal} \mathrm{yr} \mathrm{BP}$, respectively (fig. 3 ). Over the same time interval, a potentially rapid decrease in \%terrigenous seems to take place in ODP 658, although its exact timing, shape and duration cannot be precisely addressed owing to a hiatus, which spans the time interval 17,400 to 14,300 cal yr BP [deMenocal et al., 2000b]. During the deglaciation, records from site ODP 658 and core $74 \mathrm{KL}$ show a similar peak in dust supply, which appears to be coeval with the Younger Dryas episode (within the uncertainties of age models). This peak ends up abruptly in both records, and is followed by a well-defined interval of low dust supply spanning the time interval between $\sim 11,000$ to $\sim 8,000$ cal yr BP, with a peak minimum at about 10,000 cal yr BP (fig. 3). After $\sim 7,000$ cal yr BP, the evolution of Atlantic and Arabian sea records is no longer similar. The Atlantic record displays a clear increase in dust supply with a sharp jump at about $\sim 5,500 \mathrm{cal} \mathrm{BP}$, leading to \%terrigenous values in the late Holocene that are similar to those measured in the glacial interval. In the Arabian sea record, however, after a peak value around 7,000 cal $\mathrm{yr} \mathrm{BP}$, the \%dolomite decreases progressively towards the present, suggesting a less arid climate and/or a decrease in aeolian transport, which is at odds with continental data.

It is striking that tropical Atlantic and Arabian sea dust records show very similar fluctuations from the glacial to the mid-Holocene (fig. 3). It could be tempting to suggest that these fluctuations reflect synchronous aridity/humidity changes (within the limits of the age uncertainties) taking place over a tropical band extending from the eastern Atlantic to the northern Indian ocean. The reality is likely more complex, however, and other factors than monsoon-related changes in humidity might be at play. As far as core $74 \mathrm{KL}$ is concerned, for instance, Sirocko et al. [1993] suggested that part of the difference in \%dolomite between the glacial period and the late Holocene (fig. 3) does not reflect changes in monsoon dynamics but results from the flooding of the Arabo-Persian gulf. The role of lowered sea level on the amount of glacial aeolian material transported to the Arabian sea was suggested also by Preusser et al. [2002]. With an average water depth of $50 \mathrm{~m}$ and a maximum depth of $90 \mathrm{~m}$, the shallow Arabo-Persian gulf had totally dried out during the last glacial, providing a potentially important source of dolomite dust for aeolian transport that may have decreased during deglaciation, when sea level reached the transgression threshold in this area $(\sim 100-65 \mathrm{~m}$ below modern sea level [Sarnthein, 1972]). This interpretation is coherent with the evolution of shoreline in the Persian gulf from ${ }^{14} \mathrm{C}$-dated samples [Lambeck, 1996]. When converted to calibrated ages using the CALIB6.0 software [Stuiver and Reimer, 1993; Stuiver et al., 2005] with the Marine 09

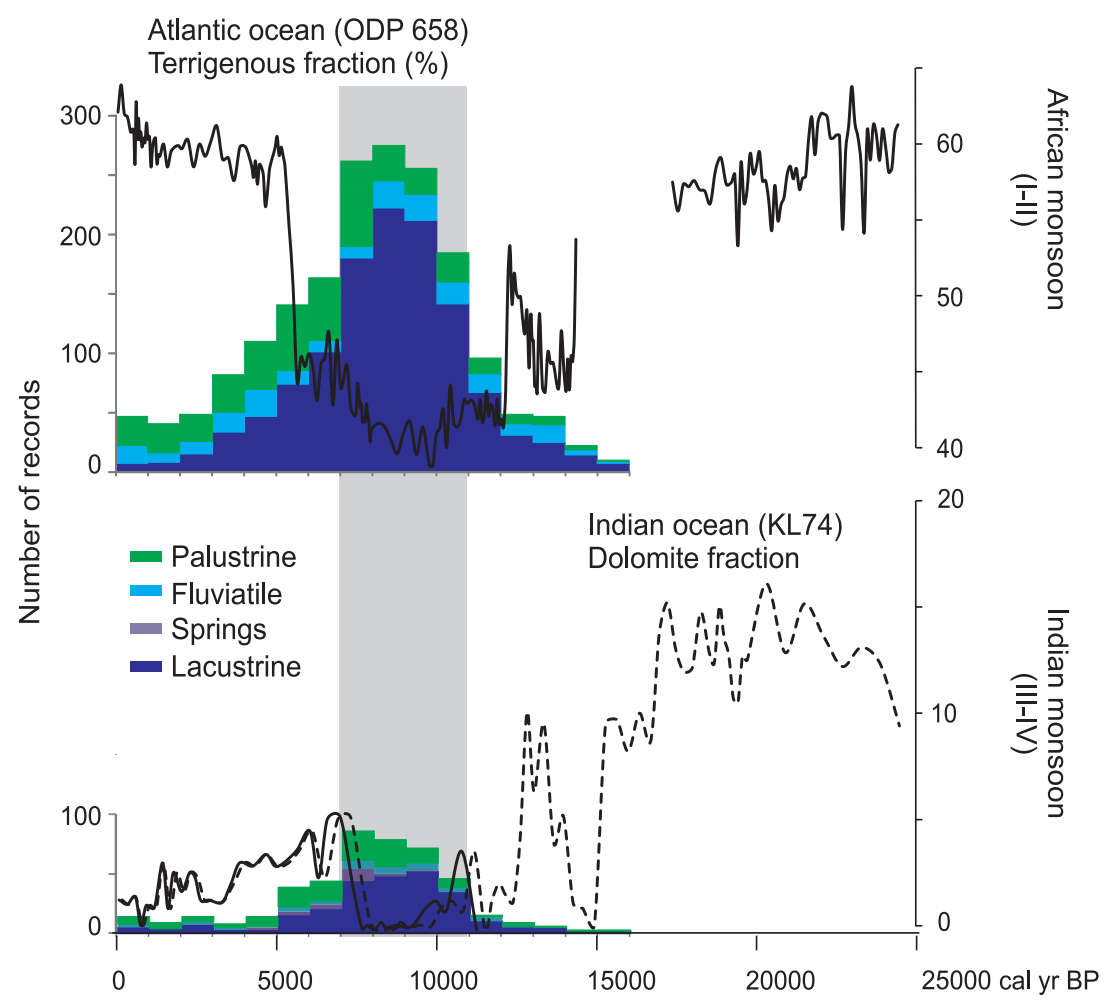

FIG. 3. - The Holocene humid period: marine and continental records of the Holocene humid period in the Atlantic and Indian monsoon sectors. Marine data are from de Menocal et al. [2000] (ODP site 658) and Sirocko et al. [1993] (74KL). Continental data were grouped according to the dominant influence of the African (I-II) and Indian monsoon (III-IV) systems (western Indian records (V) excluded). Solid line corresponds to Saliege et al. [2005]'s age model while doted line corresponds to the original one. Note the strong dissymetry of the Arabian dust record on both sides of the Holocene humid period compared to the Atlantic one. This probably accounts for the postglacial flooding of the Arabo Persian gulf from which most of the dust originated during the glacial period. 
calibration curve [Reimer et al., 2009], Lambeck's data suggest that the strait of Hormuz opened up around $\sim 17,000$ cal yr BP and that the flooding of the eastern Gulf of Persia had already started by $\sim 14,900$ cal yr BP. In support for such a role of sea-level on the availability of dolomite dust, Sirocko et al. [1993] noticed that, within the limits of core $74 \mathrm{KL}$ age model, the second drop in \%dolomite (centered at about $\sim 15,100$ cal yr BP) is associated with a simultaneous, sharp decrease in $\delta^{18} \mathrm{O}$, which was interpreted as meltwater pulse Ia, the first abrupt rise of sea level resulting from the post-glacial ice sheet melting.

Thus, aeolian proxies are complex to interpret, and past changes in aridity over adjacent continental areas may just be one among several factors to take into account in order to explain changes in windborne deposits. In order to help us decipher the real meaning of tropical Atlantic and Arabian sea dust records over the time interval from 15,000 cal $\mathrm{yr}$ BP to the present and provide a more accurate picture of mechanisms at play and the role of monsoon-related changes, we propose to take advantage of our extensive continental database by comparing the two marine records with aridity/humidity data from adjacent continental areas.

\section{DISCUSSION}

The early onset of the Holocene humid phase (circa 15,500 cal yr BP) has been evidenced in northern tropical Africa by the rise in lake levels [Gasse, 2000; de Menocal et al., 2000; Shanahan et al., 2006]. However, this early wet phase is thought to have been limited [Lézine et al., 2011], which does not seem to account satisfactorily for the abrupt and large drop in terrigenous flux observed at ODP Site 658 (fig. 3). The discrepancy between marine and continental evidence is even more striking for the Arabian peninsula where no lacustrine deposit or speleothem record has been found prior to $\sim 10,500$ cal yr BP [e.g. Fleitmann et al., 2007; Van Rampelbergh et al., 2013], making it difficult to interpret the sharp decrease in \%dolomite (fig. 3) and non- $\mathrm{CaCO}_{3}$ material [Sirocko et al., 1993] around 15,100 cal yr BP in core $74 \mathrm{KL}$ as resulting mainly from an increase in continental humidity. As we have seen above, Sirocko et al. [1993] suggested that the decrease \%dolomite at the site of core $74 \mathrm{KL}$ since the glacial could be partly related to the flooding of the Arabo-Persian gulf during the deglaciation. Other mechanisms could be also invoked, such as changes in the transport of particles (strength and/or pathway of the wind systems). The drop in dust supply could, for instance, correspond to a geographical shift of the main Arabian aerosol plume away from the location of core $74 \mathrm{KL}$ or a decrease in the convectional uplifting of this lithogenic material in the troposphere. In their 1991 publication, Sirocko et al. produced distribution maps of sedimentary material in the western Arabian sea averaged over two time intervals: 15-27,000 and 0-8,000 cal yr BP. Although the time resolution of these time slices is very coarse, the maps suggest that not only the amount of dolomite but also its geographic distribution may vary through time. Similarly, the apparent abruptness and early occurrence in the \%terrigenous drop at ODP Site 658 (over a time period when continental data only suggest limited increase in precipitation) might not reflect an aridity signal but could result from a geographical shift in the main path of the African dust plume and/or an insufficient upward transfer of dusts to the mid-troposphere. Today, large latitudinal shifts of the African dust plume are experienced on a seasonal and inter-annual basis, with sites located southwards of ODP 658 experiencing winter rather than summer maximum in dust supply [e.g. Chiapello et al., 1995].

During the deglaciation, the Atlantic and Arabian sea aeolian records show a similar, positive peak in dust supply that ends up at about $12,300 \mathrm{cal}$ yr BP and was interpreted in ODP 658 as corresponding to a dry episod that took place during the Younger Dryas (YD) chronozone [deMenocal et al., 2000a]. This episode of high aeolian dust supply corresponds to the lowering of the lake levels in the main hydrological basins of north tropical Africa [Gasse, 2000; Shanahan et al., 2006]. Nevertheless, this dry episode is not clearly documented in our continental database. This suggests that the peak in dust supply associated to the YD at ODP 658 may either result from a change in seasonality or correspond to a highly heteregeneous distribution of precipitations, which is improperly taken into account by our patchy continental database. Similarly to what we have suggested above for the late glacial signal, the marine peak in dust supply may also reflect a change in atmospheric circulation dynamics and the transport of lithogenic material (i.e. increased activity of the convective cells that uplift the lithogenic material to the mid-troposphere, and/or shift in the latitudinal position of the jets that carry the dust plume to the marine sites). As far as the Arabian area is concerned, it is striking to notice that the $\% \mathrm{CaCO}_{3}$ record of core $74 \mathrm{KL}$, which is also interpreted as reflecting aridity over Arabia, does not show a YD peak contrary to the \%dolomite record [Sirocko et al., 1993]. The difference between these two indicators is not fully understand at present and could reflect contrasts in spatial distribution and transport. The YD peak aridity suggested by the maximum in \%dolomite seems to be confirmed, however, by a coeval increase in dust flux observed in sediments from the northern Arabian sea [Pourmand et al., 2004].

As we have just seen above, discrepancies between the marine dust records and continental records suggest that atmospheric circulation and the geographical distribution of windborne material -rather than changes in aridity/humidity- may largely explain the major features observed in the dust records from ODP 658 and core $74 \mathrm{KL}$, over the time interval lasting from the end of the last glacial to the Younger Dryas chronozone. Changes in humidity are, however, the primary mechanism that should be invoked to explain the low values of dust indexes recorded between 11,000 and 7,000 cal yr BP in ODP 658 and core 74KL. Indeed, it is during this time interval that the largest number of dated lake sediments has been obtained over north tropical Africa and Arabia. The strong anti-correlation between continental humidity indexes and records of marine dust supply (fig. 3) clearly indicates that this early Holocene low in windborne material can be confidently attributed to changes in monsoon-related precipitation onland [Sirocko et al., 1991, 1993; deMenocal et al., 2000a,b]. This conclusion is further supported by changes in $\mathrm{Sr}$ isotopic signature and chemical compositions of lithogenic material in sediments from ODP 658. During this time interval, ${ }^{87} \mathrm{Sr} /{ }^{86} \mathrm{Sr}$ ratios are markedly less radiogenic, and sediments show higher chemical indices of alterations, suggesting an increased authigenic sediment supply from extensive North African paleolake basins 
[Cole et al., 2009]. Pollen data from southern Arabia, however, clearly show that the landscape remained of desert/ semi-desert type all along the Holocene wet period [Lézine et al., 1998; 2007] contrary to what happened in northern Africa where tropical ecosystems widely expanded [Watrin et al., 2009]. The paucity of Holocene lacustrine deposits and the continuous edification of sand dunes (fig. 2) in southern Arabia confirm that regional dry conditions persisted in the Arabian peninsula during the Holocene wet phase. In this context, the near absence of dust transport to core $74 \mathrm{KL}$ site is highly surprising.

Towards the end of the humid period, the drying out of humid areas in Arabia corresponds to the reactivation of the

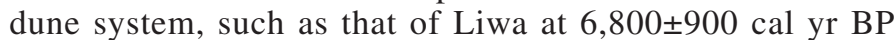
[Bray and Stokes, 2004] and to the increase in \%dolomite observed in core 74KL (fig. 3). In northern Africa however, the end of the Holocene wet phase occurred at least 1,000 years later according to ODP 658 [deMenocal et al., 2000b]. This site records an increase off western african windborne material from 5,500 cal yr BP onward, reaching values in the late Holocene as high as those recorded during the last glacial period. That globally mimics the orbital forcing with high terrigenous values in phase with low insolation, and vice versa. High \%terrigenous during the late Holocene have been interpreted as reflecting the denudation of the continental surfaces due to increased aridity in the Sahara and Sahel. Our paleohydrological database shows, however, that humid conditions locally persisted, particularly in the western Sahel, after 5,500 cal yr BP. That is confirmed by pollen data which show that the present-day arid conditions were reached at 2,700 cal yr BP only in northern Chad [Lézine et al., 2011b] and that Rhizophora, a tropical humid mangrove element, persisted along the littoral of Mauritania up to 2,400 cal yr BP [Lézine and Hooghiesmtra, 1990; Lézine, unpublished: http://fpd.sedoo.fr]. In the Arabian sea, core $74 \mathrm{KL}$ provides a complex signal with late Holocene terrigenous values considerably lower (2.5 time) compared to the last glacial ones, probably related to the modification of the source zone and particularly the flooding of the Arabo-Persian gulf.

\section{CONCLUDING REMARKS}

Two main results emerge from our study:

1) the hydrological response to the Holocene humid phase in northern tropics strongly differs from a region to another. If the maximum humidity is roughly contemporaneous in both the Atlantic and Indian monsoon areas (11-7000 cal yr BP), the humid period is significantly shorter in the Arabian peninsula and the horn of Africa, starting from 12-11,000 cal yr BP instead of 15,500 cal yr $\mathrm{BP}$ in northern Africa. Similarly, it ended earlier at ca 6,500-7,000 cal BP (at least in the lowlands) instead of $5,500-4,500$ cal yr BP. In western India, the hydrological response to increased rainfall at the beginning of the Holocene mainly results in the activation of fluvial systems. Lakes are scarce compared to other regions and display a different distribution with a peak delayed toward the mid Holocene (8000-7000 cal yr BP);

2) the terrigenous signal from marine cores is complex, being not only associated with aridity/humidity changes but likely integrating changes in source zones, (e.g., the drying of the Arabo-Persian gulf during the last glacial period), and/or changes in wind intensity and direction. In order to better decipher between atmospheric transport and changes in humidity/aridity, further studies will be conducted, including reconstruction of sea surface salinities from coupled $\mathrm{Mg} / \mathrm{Ca}-\delta^{18} \mathrm{O}$ analyses on planktonic foraminifers and the careful examination of GCM reconstructions of wind circulation at different altitudes for the LGM, early Holocene and mid Holocene.

Acknowledgements. - This research has been funded by the National Agency for Research in France (projet ANR-vulnerability "SAHELP" (ANR-06-VULN-015) and "El PASO" (ANR-10-BLAN-0608). Thanks are due to all the projects partners for fruitfull discussions. A-ML is supported by CNRS and FB and J-YP by CEA. The full hydrological dataset will be stored at the NOAA-Paleoclimatology database.

\section{References}

ACKeRMAN S.A. \& Cox S.K. (1988). - Dust outbreaks associated with the southwest monsoon region. - Meteor. Atmosph. Phys., 41, 19-34.

Adkins J., DeMenocal P. \& Eshel G. (2006). - The "African humid period" and the record of marine upwelling from excess $230 \mathrm{Th}$. In: Ocean Drilling Program Hole 658C. - Paleoceanography, 21, PA4203, doi: 10.1029/2005PA001200.

Bassinot F.C., Marzin C., Braconnot P., Marti O., Mathien-Blard E., LOMBARD F. \& BOPP L. (2011). - Holocene evolution of summer winds and marine productivity in the tropical Indian ocean in response to insolation forcing: data-model comparison. - Clim. Past, 7, 815-829.

Berger A. \& Loutre M.F. (1991). - Insolation values for the climate of the last 10 million years. - Quat. Sci. Rev., 10, 297-317.

Bourget J., Zaragosi S., Ellouz-Zimmermann S., Ducassou E., Prins M.A., Garlan T., Lanfumey V., Schneider J.L., Rouillard P. \& Giraudeau J. (2010). - Highstand vs. lowstand turbidite system growth in the Makran active margin: Imprints of high-frequency external controls on sediment delivery mechanisms to deep water systems. - Mar. Geol., 274, 187-208.
Braconnot P., Marzin C., Grégoire L. Mosquet E. \& Marti O. (2008). Monsoon response to changes in Earth's orbital parameters: comparisons between simulations of the Eemian and of the Holocene. - Clim. Past, 4, 2, 459-493.

BRAY H.E. \& STOKES S. (2004). - Temporal patterns of arid-humid transitions in the southeastern Arabian peninsula based on optical dating. - Geomorphology, 59, 271-280.

Chiapello I., Bergametti G., Gomes L. \& Chatenet B. (1995). - An additional low layer transport of Sahelian and Saharan dust over the northeastern tropical Atlantic. - Geophys. Res. Lett., 22, 23, 3191-3194.

Clemens S.C. \& Prell W.L. (1990). - Late Pleistocene variability of Arabian sea summer monsoon winds and dust source area aridity: A record from the lithogenic component of deep-sea sediments. Paleoceanography, 5, 109-145.

COHMAP MEMBERS (1988). - Climatic changes of the last 18,000 years: Observations and model simulations. - Science, 241, 365-379. 
Cole J.M., Goldstein S.L., DeMenocal P.B., Hemming S.R. \& Grousset F. (2009). - Contrasting compositions of Saharan dust in the eastern Atlantic ocean during the last deglaciation and African humid period. - Earth Planet. Sci. Lett., 278, 257-266.

deMenocal P., Ortiz J., Guilderson T., Adkins J., Sarnthein M., Baker L. \& YARUNSINSKY M. (2000a). - Abrupt onset and termination of the African humid period: rapid climate responses to gradual insolation forcing. - Quat. Sci. Rev., 19, 347-361.

deMenocal P., Ortiz J., Guilderson T. \& Sarnthein M. (2000b). - Coherent high- and low-latitude climate variability during the Holocene warm period. - Science, 288, 2198-2202.

EL-SAYED M.I. (1999). - Sedimentological characteristics and morphology of the aeolian sand dunes in the eastern part of the UAE: case study from Ar Rub' Al Khali. - Sedim. Geol., 123, 219-238.

Fleitmann D., Burns S.J., Mangini A., Mudelsee M., Kramers J., Villa I., Neff U., Al-Subbary A.A., Buettner A., Hippler D. \& MATTER A. (2007). - Holocene ITCZ and Indian monsoon dynamics recorded in stalagmites from Oman and Yemen (Socotra). Quat. Sci. Rev., 26, 170-188.

Fontes J.-C. \& GASSE F. (1991). - Palhydaf (paleohydrology in Africa) program: objectives, methods, major results. - Palaeogeogr., $\mathrm{Pa}$ laeoclimatol., Palaeoecol., 84, 191-215.

GASSE F. (2000). - Hydrological changes in the African tropics since the Last Glacial maximum. - Quat. Sci. Rev., 19, 189-211.

Giosan L., Clift P.D., Macklin M.G., Fuller D.Q., Constantinescu S., Durcan J.A., Stevens T., Duller G.A.T., Tabrez A.R., Gangal K., Adhikari R., Alizai A., Filip F., vanLaningham S. \& SYVITSKI J.P.M. (2012). - Fluvial landscapes of the Harappan civilization. - PNAS, 10.1073/pnas.1112743109.

Goudie A.S. \& Middleton N.J. (2000). - Saharan dust storms: nature and consequences - Earth Sci. Rev., 56, 179-204.

Grousset F.E., Parra M., Bory A., Martinez P., Bertrand P., Shimield G. \& Ellam R.M. (1998). - Saharan wind regimes traced by the Sr-Nd isotopic composition of subtropical Atlantic sediments: last glacial maximum vs. today. - Quat. Sci. Rev., 17, 395-409.

Gupta A.K., Anderson D.M. \& Overpeck J.T. (2003). - Abrupt changes in the Asian southwest monsoon during the Holocene and their links to the North Atlantic ocean. - Nature, 421, 355-357.

Joussaume S., Taylor K.E., Braconnot P., Mitchell F.B., Kutzbach E., Harrison S.P., Prentice I.C., Broccoli A.J., Abe-Ouchi A., Bartlein J., Bonfils C., Dong B., Guiot J., Henerich K., HewitT C.D., Jolly D., Kim J.W., Kislov A., Kitoh A., Loutre M.F., Masson V., McAvaney B., McFarlane N., de Noblet N., Peltier W.R., Peterschmitt J.Y., Pollard D., Rind D., Royer F., Schlesinger M.E., Syktus J., Thompson S., Valdes P., Vettoretti G., Webb R.S. \& Wyput U. (1999). - Monsoon changes for 6000 years ago: Results of 18 simulations from the Paleoclimate Modeling Intercomparison Project (PMIP). - Geophys. Res. Lett., 26, 7, 859-862.

Kröpelin S., Verschuren D., LéZine A.-M., Eggermont H., Cocquyt C., Francus P., Cazet J.-P., Fagot M., Rumes B., Russell J.M., Darius F., Conley D.J., Schuster M., von Suchodoletz H. \& ENGSTROM D.R. (2008). - Climate-driven ecosystem succession in the Sahara: the past 6000 years. - Science, 320, 765-768.

KÜPER R. \& KRÖPELIN S. (2006). - Climate-controlled Holocene occupation in the Sahara: Motor of Africa's evolution. - Science, 313, 5788, 803-807, doi: 10.1126/Science. 1130989.

LAMBECK K. (1996). - Shoreline reconstructions for the Persian gulf since the last glacial maximum. - Earth Planet. Sci. Let., 142, 43-57.

Laskar J., Robutel P., Joutel F., Gastineau M., Correia A.C.M. \& LEVRARD B. (2004). - A long-term numerical solution for the insolation quantities of the Earth. - Astronomy and Astrophysics, 428, 261-285.

Lézine A.-M., Hély C., Grenier C., Braconnot P. \& Krinner G. (2011a). Sahara and Sahel vulnerability to climate changes, lessons from paleohydrological data. - Quat. Sci. Rev., 30, 21-22, 3001-3012.

Lézine A.-M., Zheng W., Braconnot P. \& Krinner G. (2011b). - Late Holocene plant and climate evolution at lake Yoa, northern Chad: pollen data and climate simulations. - Clim. Past, 7, 1351-1362.

LÉZine A.-M. \& Hooghiemstra H. (1990). - Land-sea comparisons during the last glacial-interglacial transition: pollen records from West Tropical Africa. - Palaeogeogr., Palaeoclimatol., Palaeoecol., 79, 3-4, 313-331.
Lézine A.-M., Robert C., Cleuziou S., Inizan M.-L., Braemer F., Saliège J.-F., Sylvestre F., Tiercelin J.-J., Crassard R., Méry S., Charpentier V. \& Steimer-Herbet T. (2010). - Climate evolution and human occupation in the southern Arabian lowlands during the last deglaciation and the Holocene. - Glob. Planet. Change, 72, 4, 412-428

Lézine A.-M., Saliège J.-F., Robert C., Wertz F. \& Inizan M.-L. (1998). - Holocene lakes from Ramlat As-Sab'atayn (Yemen) illustrate the impact of monsoon activity in southern Arabia. - Quatern. Res., 50, 290-299.

Lézine A.-M., Tiercelin J.-J., Robert C., Saliège J.-F., Cleuziou S., IniZAN M.-L. \& BRAEMER F. (2007). - Centenial to millenial-scale variability of the Indian monsoon during the early Holocene from a sediment, pollen and isotope record from the desert of Yemen. - Palaeogeogr., Palaeoclimatol., Palaeoecol., 243, 235-249.

Liu Z., Otto-Bliesner B., Kutzbach J., Li L. \& Shields C. (2003). - Coupled climate simulation of the evolution of global monsoons in the Holocene. - J. Clim., 16, 2472-2490.

MARZin C. \& BRAConnot P. (2009). - Variations of Indian and African monsoons induced by insolation changes at 6 and $9.5 \mathrm{kyr}$ BP. Clim. Dyn., 33, 2-3, 215-231.

Middleton N.J. (1986). - A geography of dust storms in south-west Asia. - J. Climat., 6, 183-196.

NDEYE M. (2008). - Marine reservoir ages in northern Senegal and Mauritania coastal waters. - Radiocarbon, 50, 281-288.

Ohgatto R. \& Abe-Ouchi A. (2007). - The role of ocean thermodynamics and dynamics in Asian summer monsoon changes during the Mid-Holocene. - Clim. Dyn., 29, 1, 39-50.

Paillard D., LABeyrie L. \& Yiou P. (1996). - Macintosh program performs time-series analysis. - Eos Trans. AGU, 77, 379.

Pourmand A., Marcantonio F. \& Schulz H. (2004). - Variations in productivity and eolian fluxes in the northeastern Arabian sea during the past $110 \mathrm{ka}$. - Earth Planet. Sci. Lett., 221, 39-54.

Prell W.L. \& KutzBach J.E. (1987). - Monsoon variability over the past 150,000 years. - J. Geophys. Res., 92, 8411-8425.

PRELl W.L. \& VAN CAMPo E. (1986). - Coherent response of Arabian sea upwelling and pollen transport to late Quaternary monsoonal winds. - Nature, 323, 526-528.

Preusser F., RAdies D. \& MATTER A. (2002). - A 160,000-year record of dune development and atmospheric circulation in southern Arabia. - Science, 296, 2018-2020

Pye K. (1987). - Aeolian dust and dust deposits. - Acad. Press, London, 334 pp.

Van Rampelbergh M., Fleitmann D., Verheyden S., Cheng H., Edwards L., De Geest P., De vleeschouwer D., Burns S.J., Matter A., Claeys P. \& Keppens E. (2013). - Mid- to late Holocene Indian Ocean monsoon variability recorded in four speleothems from Socotra island, Yemen. - Quat. Sci. Rev., 65, 129-142.

Reimer P.J., Baillie M.G.L., Bard E., Bayliss A., Beck J.W., Blackwell P.G., Bronk Ramsey C., Buck C.E., Burr G.S., Edwards R.L., Friedrich M., Grootes P.M., Guilderson T.P., Hajdas I, HeAton T.J., Hogg A.G., Hughen K.A., Kaiser K.F., Kromer B., McCormac F.G., Manning S.W., Reimer R.W., Richards D.A., Southon J.R., Talamo S., Turney C.S.M., van der Plicht J. \& WEYHENMEYER C.E. (2009). - IntCal09 and Marine09 radiocarbon age calibration curves, 0-50,000 years cal BP. - Radiocarbon, 51, 4, 1111-50.

Saliège J-F, Lézine A.-M. \& Cleuziou S. (2005). - Estimation de l'effet réservoir ${ }^{14} \mathrm{C}$ marin en mer d'Arabie. - Paléorient, 31, 1, 35-43.

SARNTHEIN M. (1972). - Sediments and history of the postglacial transgression in the Persian gulf and northwest gulf of Oman. - Mar. Geol., 12, 245-266.

SARnTHEIN M. (1978). - Sand deserts during the glacial maximum and climate optimum. - Nature, 272, 43-46.

Savoie D.L., Prospero J.M. \& Nees R.T. (1987). - Nitrate, non sea sulfate, and mineral aerosol over the northwestern Indian Ocean. - $J$. Geophys. Res., 92, 933-412.

Schepanski K., Tegen I., Laurent B., Heinold B. \& Macke A. (2007). A new Saharan dust source activation frequency map derived from MSG-SEVIRI IR-channels. - Geophys. Res. Lett., 34, L18803, doi: 10.1029/2007GL030168.

Schültz L., Jaenicke R. \& Pietrek H. (1981). - Saharan dust transport of the North Atlantic ocean. - Geol. Soc. Amer. Bull., Spec. Pap., 186, $87-100$. 
Shanahan T.M., Overpeck J.T., Wheeler C.W., Beck J.W., Pigati J.S., Talbot M.R., Scholz C.A., Peck J. \& King J.W. (2006). - Paleoclimatic variations in West Africa from a record of late Pleistocene and Holocene lake level stands of Lake Bosumtwi, Ghana. Palaeogeogr., Palaeoclimatol., Palaeoecol., 242, 287-302.

Sinha R., Kumar R., Sinah S., TAndon S.K. \& Gibling M.R. (2007). Late Cenozoic fluvial successions in northern and western India: an overview and synthesis. - Quat. Sci. Rev., 26, 2801-2822.

Sirocko F., Sarnthein M., Erlenkeusers H., Lange H., Arnold M. \& DuPLESSY J.-C. (1993). - Century-scale events in monsoonal climate over the past 24,000 years. - Nature, 364, 322-324.

Sirocko F., Sarnthein M., Lange H. \& Erlenkeuser H. (1991). - Atmospheric summer circulation and coastal upwelling in the Arabian sea during the Holocene and the Last Glaciation. - Quat. Res., 36, 72-93.

Southon J, Kashgarian M, Fontugne M, Metivier B. \& Yim W. (2002). Marine reservoir corrections for the Indian ocean and Southeast Asia. - Radiocarbon, 44, 167-180.

Stuiver M. \& Reimer P.J. (1993). - Extended ${ }^{14} \mathrm{C}$ database and revised CALIB $3.0{ }^{14} \mathrm{C}$ age calibration program. - Radiocarbon, 35, $215-230$.
Stuiver M. \& Reimer P. J. (1986). - A computer program for radiocarbon age calibration. - Radiocarbon, 28, 1022-1030.

Stuiver M., Reimer P.J. \& Reimer R.W. (2005). - CALIB 6.0 software (http://calib.qub.ac.uk/cal/ib).

Tetslaff G. \& Wolter K. (1980). - Meteorological patterns and the transport of mineral dust from the North African continent. - Paleoecol. Africa, 12, 31-42.

Van CAmpo E., Duplessy J.-C. \& Rossignol-Strick M. (1982). - Climatic conditions deduced from a $150 \mathrm{kyr}$ oxygen isotope-pollen record from the Arabian sea. - Nature, 296, 56-59.

Van Rampelbergh M., Fleitmann D., Verheyden S., Cheng H., Edwards L., De Geest P., De Vleeschouwer D., Burns S.J., Matter A., Claeys P. \& Keppens E. (2013). - Mid- to late Holocene Indian ocean monsoon variability recorded in four speleothems from Socotra island, Yemen. - Quat. Sci. Rev., 65, 129-142.

Washington R., Todd M., Middleton N.J. \& Goudie A.S. (2003). Dust-storm source areas determined by the total ozone monitoring spectrometer and surface observations. - Ann. Assoc. Am. Geogr., 93, 297-313.

WATRIN J., LÉZINE A.-M. \& HÉLY C. (2009). - Plant migration and ecosystems at the time of the "green Sahara". - C. R. Geoscience, $\mathbf{3 4 1}$, 656-670. 